\title{
EFEKTIVITAS PEMBINAAN KEMANDIRIAN NARAPIDANA DI LEMBAGA PEMASYARAKATAN WIROGUNAN YOGYAKARTA
}

\author{
Muhammad Ali Equatora \\ Politeknik Ilmu Pemasyarakatan, Depok \\ Email: bangtora1973@gmail.com
}

Received: $16^{\text {th }}$ January 2018; Revised: $18^{\text {th }}$ February 2018; Accepted: $19^{\text {th }} J^{\text {June }} 2018$

\begin{abstract}
Research on the effectiveness in coaching independence prisoners in Wirogunan Yogyakarta has begun and aims to determine the effectiveness in coaching independence inmates start with the implementations aimed at the realization of prisoners who have selfreliance skills. This study used a qualitative descriptive approach, where the primary data found by asking questions of the officials on issues related to assimilation processing job (coaching independence) from both structural field officials. Base on the research, it is known that the effectiveness of coaching independence inmates still not optimal condition apart from several factor, including the human factor other support, human resources, process guidance, available budget and bureaucracy. Effort needs to be done to overcome obstacles in coaching independence inmates were cooperating with the government agencies and institutions in an effort to increase public guidance to prisoners; strong motivation from the persons with the principles of morality and idealist; the effort to improve the walfare agency officials to increase the loyality of officers in carrying out the existence of moral. Researchers sugget the necessity of an understanding of the responsibilities in coaching independent prisoners with all parties, especially the components in the criminal justice system such as police, prosecutors, and court to actively enroll people, and the government and the private sector in efforts to confront obstacles in the face of prison.
\end{abstract}

Keyword: effectiveness, coaching, independence, prisoners.

Abstrak. Penelitian tentang efektifitas pembinaan pada para narapidana yang bebas di Wirogunan Yogyakarta bertujuan guna menentukan efektifitas pembinaan atas mereka yang dimulai dengan berbagai implementasi untuk mewujudkan tahanan yang memiliki keterampilan kemandirian diri. Studi ini menggunakan pendekatan deskriptif kualitatif di mana data primer diperoleh dengan mengajukan pertanyaan pada petugas resmi terkait isu pekerjaan proses asimilasi (melatih tahanan yang bebas) dari petugas yang terbagi secara struktural. Berdasarkan riset ini, diketahui bahwa efektifitas pembinaan narapidana jauh dari kondisi optimal terkait beberapa faktor yang meliputi faktor kemanusiaan, seperti dukungan, sumber daya manusia, pembinaan, ketersediaan anggaran, dan birokrasi. Upaya yang diperlukan untuk mengatasi tantangan pembinaan narapidana yang bebas adalah bekerjasama dengan agen-agen pemerintah dan berbagai lembaga guna meningkatkan peningkatkan pembinaan narapidana, motivasi yang kuat dari orang-orang beserta prinsip-prinsip moralitas dan idealisme, upaya meningkatkan kesejahteraan oleh petugas guna meningkatkan loyalitas dalam mengemban eksistensi moral. Peneliti menyarankan perlunya pemahaman tanggung jawab dalam membina narapidana bebas dengan seluruh bagian-bagiannya khususnya komponen-komponen di dalam sistem keadilan hukum seperti polisi, jaksa, dan pengadilan agar secara aktif mendaftarkan masyarakat, pemerintah dan sektor privat dalam upaya mengatasi tantangan menghadapi narapidana.

Kata Kunci: efektifitas, pembinaan, kebebasan, narapidana. 


\section{Pendahuluan}

Pembinaan kemandirian narapidana di Indonesia diterapkan dengan sistem pemasyarakatan. Sistem ini telah dicetuskan dan diaplikasikan sejak tahun 1964 . Namun pengaturan sistem tersebut secara sistematis dalam bentuk undang-undang dan perangkat aturan pendukungnya baru dapat diwujudkan pada tahun 1995, melalui Undang-undang Nomor 12 tahun 1995 tentang pemasyarakatan. Sistem pemasyarakatan bertujuan untuk membentuk warga binaan pemasyarakatan agar menjadi manusia seutuhnya, menyadari kesalahan, memperbaiki diri dan tidak mengulangi tindak pidana sehingga dapat diterima kembali oleh lingkungan masyarakat, dapat aktif berperan dalam pembangunan, dan dapat hidup secara wajar sebagai warga yang baik dan bertanggung jawab.

Secara umum pembinaan kemandirian harus ditingkatkan melalui pendekatan pembinaan keterampilan, meliputi pemulihan harga diri sebagai pribadi maupun sebagai warga negara yang menyakini dirinya masih memiliki potensi produktif bagi pembangunan bangsa dan oleh karena itu mereka dididik juga untuk menguasai keterampilan tertentu guna dapat hidup mandiri dan berguna bagi pembangunan. Berdasarkan latar belakang masalah di atas, maka penelitian ini akan membahas tentang "Efektivitas Pembinaan Kemandirian Narapidana di Lembaga Pemasyarakatan Wirogunan Yogyakarta".

\section{Metode}

Metode dapat diartikan sebagai prosedur atau rangkaian cara yang sistematik dalam menggali kebenaran. Selanjutnya metodologi adalah ilmu tentang metode, yang dipergunakan dalam melakukan kegiatan penelitian. Metode yang dipergunakan dalam penelitian ini termasuk pada penelitian kualitatif dengan deskriptif sederhana. Metode deskriptif adalah metode dalam meneliti suatu kelompok manusia, suatu obyek, suatu set kondisi, suatu sistem, pemikiran suatu kelompok, sistem ataupun suatu kelas peristiwa pada masa sekarang, yang bertujuan untuk deskripsi, gambaran, lukisan secara sistematis aktual dan akurat mengetahui fakta-fakta serta sifat-sifat serta hubungannya antara fenomena yang diselidiki. Sedangkan pendekatan yang digunakan adalah induktif. Pendekatan induktif menurut Nazir adalah cara berpikir untuk memberi alasan yang dimulai dengan pernyataan-pernyataan yang spesifik untuk menyusun suatu argumentasi yang bersifat umum. Dalam alasan induktif suatu kesimpulan ditarik dari pernyataan spesifik (Ali Nazir, 1999:202).

Jadi dengan menggunakan pendekatan ini, sesuai dengan masalah yang diteliti 
maka penulis akan berusaha menggambarkan data atas gejala-gejala di lapangan yang bersifat khusus kemudian dihubungkan dengan teori yang relevan atau sesuai sehingga menghasilkan suatu kesimpulan yang bersifat umum. Untuk mengarahkan proses analisis sehingga menemukan strategi-strategi yang dituju, maka digunakan model analisis manajemen atau perencanaan strategis (strategic planning), suatu disiplin yang bertujuan menghasilkan keputusan-keputusan dan kegiatan-kegiatan mendasar yang mengarah pada bagaimana program organisasi dilakukan, apa yang seharusnya dilakukan dan mengapa itu harus dilakukan.

\section{Hasil dan Diskusi}

\section{Input}

Input adalah komponen tahap pertama yang akan menjadi masukan dalam suatu sistem. Komponen ini akan memberikan informasi yang akan sangat dibutuhkan di dalam proses suatu sistem. Salah satu informasi yang didapat dari input adalah sumber daya manusia. Kegiatan Pembinaan Kemandirian Narapidana di Lembaga Pemasyarakatan Wirogunan Yogyakarta berdasarkan surat keputusan Kepala Lembaga Pemasyarakatan Wirogunan Yogyakarta. Adapun sumber daya manusia yang merupakan salah satu indikator dari input dalam penelitian ini telah dibentuk oleh pihak Lembaga Pemasyarakatan Wirogunan Yogyakarta yaitu Penanggung Jawab Pembinaan Kemandirian Narapidana dan diikuti pembagian tugas yang cukup jelas untuk masing-masing personil tapi kenyataan keterbatasan petugas yang memberikan keterampilan sehingga menjadi tidak optimal.

Sedangkan yang berkenaan dengan sumber dana yang digunakan untuk mendanai semua keperluan dan juga kegiatan Pembinaan Kemandirian Narapidana di Lembaga Pemasyarakatan Wirogunan Yogyakarta berasal dari DIPA tahun 2017 dan juga bantuan dari pihak ketiga di Yogyakarta. Sedangkan untuk pemenuhan sarana dan prasarana Kegiatan Pembinaan Kemandirian Narapidana di Lembaga Pemasyarakatan Wirogunan Yogyakarta dapat diketahui masih kurang memadai. Hal tersebut dikarenakan terbatasnya sarana dan prasarana yang dimiliki lembaga pemasyarakatan Wirogunan Yogyakarta.

\section{Proses}

Pada komponen ini menjabarkan secara keseluruhan apa yang dilaksanakan oleh petugas pelaksana Pembinaan Kemandirian Narapidana di Lembaga Pemasyarakatan Wirogunan Yogyakarta. Sehingga suatu proses, di dalamnya terdapat tahapan-tahapan kegiatan yang tersusun secara sistematis dan berkelanjutan. 


\section{a. Proses pengusulan narapidana yang mengikuti pembinaan kemandirian.}

Pembinaan Kemandirian Narapidana merupakan asimilasi kerja yang diberikan kepada narapidana yang telah menjalani pidana $1 / 2$ dari masa pidananya untuk mendapatkan pengetahuan dan keterampilan kerja. Hal tersebut merupakan salah satu cara untuk menjadikan narapidana yang mandiri. Oleh karena itu, dibutuhkan partisipasi dan juga komunikasi antar kedua belah pihak baik dari petugas lapas maupun narapidana itu sendiri.

Proses Pengusulan Narapidana untuk mengikuti pembinaan kemandirian memiliki peran yang penting dalam terlaksananya pembinaan narapidana di Lembaga Pemasyarakatan Wirogunan Yogyakarta. Dengan adanya proses pengusulan narapidana yang mengikuti pembinaan kemandirian bisa digali seberapa besar kemauan narapidana yang akan memasuki masa $1 / 2$ dari masa pidananya untuk dikutkan dalam asimilasi kerja berupa pembinaan kemandirian.

Berdasarkan penelitian ini, kegiatan pengusulan narapidana yang mengikuti Pembinaan Kemandirian Narapidana di Lembaga Pemasyarakatan Wirogunan Yogyakarta telah dilaksanakan meskipun intensitas kegiatan pengusulan narapidana yang mengikuti pembinaan kemandirian tidak terlalu sering dilakukan. Pelaksanaan kegiatan proses pengusulan narapidana yang mengikuti pembinaan kemandirian di Lembaga Pemasyarakatan Wirogunan Yogyakarta masih banyak memiliki kekurangan dan hambatan. Salah satunya yaitu kurangnya partisipasi dan kesadaran narapidana untuk mengikuti asimilasi kerja dalam bentuk pembinaan kemandirian.

Hal tersebut mungkin dikarenakan para narapidana belum memiliki minat untuk mengikuti pembinaan kemandirian yang dilaksanakan di lapas sekayu. Kurangnya minat narapidana untuk mengikuti karena pembinaan kemandirian yang dilaksanakan terbatas dan belum menggugah mereka untuk ikut di dalamnya.

\section{b. Pembinaan Kemandirian Pertukangan/Meubelair .}

Pembinaan Kemandirian Pertukangan/Meubelair merupakan asimilasi kerja yang diberikan kepada narapidana yang memiliki minat untuk belajar dan menambah pengetahuannya di bidang pertukangan/meubelair. Pelaksanaan pembinaan kemandirian pertukangan/meubelair bertujuan agar para narapidana memiliki keterampilan dan pengetahuan bidang pertukangan/meubelair.

Maka dari itu, pihak Lembaga Pemasyarakatan Wirogunan Yogyakarta telah melaksanakan kegiatan keterampilan kerja dengan memanfaatkan sarana dan prasarana yang tersedia namun hasil belum optimal, karena pemasaran hasil pekerjaan 
narapidana belum optimal. Di samping itu, lembaga pemasyarakatan Wirogunan Yogyakarta juga melakukan kerjasama dengan pihak swasta di Kota Yogyakarta untuk memberikan pelatihan-pelatihan pekerjaan meubelair bagi narapidana di lembaga pemasyarakatan Wirogunan Yogyakarta namun di tahun 2017 kerja sama ini belum bisa terwujud.

\section{c. Pembinaan Kemandirian Perkebunan/Pertanian}

Pembinaan Kemandirian Perkebunan / Pertanian merupakan asimilasi kerja yang diberikan kepada narapidana yang memiliki minat untuk belajar dan menambah pengetahuannya di bidang perkebunan / pertanian. Pelaksanaan pembinaan kemandirian perkebunan/pertanian bertujuan agar para narapidana memiliki keterampilan dan pengetahuan bidang perkebunan/ pertanian.

Maka dari itu, pihak Lembaga Pemasyarakatan Wirogunan Yogyakarta telah berupaya untuk melakukan kerja sama dengan pihak ketiga agar bisa memberikan bantuan pembibitan serta tenaga instruktur bidang perkebunan/pertanian, sayangnya kerjasama ini masih belum terwujud sehingga kegiatan perkebunan/pertanian terbatas dalam penanaman sayur-sayuran saja. Hal ini tidak terlepas karena keterbatasan anggaran yang dimiliki lapas untuk mengalokasikan dana untuk pembinaan kemandirian perkebunan/pertanian, akibatnya pembinaan ini tidak optimal.

\section{d. Pembinaan Kemandirian Membatik}

Pembinaan Kemandirian Membatik merupakan asimilasi kerja yang diberikan kepada narapidana wanita yang memiliki minat untuk belajar dan menambah pengetahuannya di bidang membatik. Pelaksanaan pembinaan kemandirian membatik bertujuan agar para narapidana memiliki keterampilan dan pengetahuan bidang membatik. Maka dari itu, pihak Lembaga Pemasyarakatan Wirogunan Yogyakarta telah berupaya untuk melakukan kerja sama dengan pihak ketiga agar bisa memberikan bantuan bahan kerja dan juga pemasaran dari kerajinan yang dibuat narapidana wanita.

\section{Output}

Merupakan hasil pelaksanaan program seperti yang telah ditetapkan pada tujuan sebelumnya. Hasil dari pelaksanaan program tersebut merupakan tujuan yang hendak dicapai oleh pelaksanaan program tersebutyang berupa kriteria tertentu. Tujuan umum dari Pembinaan Kemandirian Narapidana di Lembaga Pemasyarakatan Wirogunan Yogyakarta adalah meningkatkan keterampilan dan pengetahuan narapidana di 
Lembaga Pemasyarakatan Wirogunan Yogyakarta dan menjadi bekal bagi narapidana ketika selesai menjalani pidana di Lembaga Pemasyarakatan Wirogunan Yogyakarta.

Pembinaan Kemandirian Narapidana ini sangatlah bermanfaat bagi narapidana yang sedang menjalani pidana di Lembaga Pemasyarakatan Wirogunan Yogyakarta karena apabila tercapai tujuan dari Pembinaan Kemandirian Narapidana ini maka akan menjadi efektif pembinaan kemandirian yang dilaksanakan oleh Lembaga Pemasyarakatan Wirogunan Yogyakarta, kegiatan ini memberikan pelatihan keterampilan bagi narapidana yang disesuaikan dengan kebutuhan masyarakat pada umumnya sehingga keterampilan yang diberikan tepat sasaran dan bisa membuat narapidana menjadi mandiri ketika selesai menjalani pidana.

Berdasarkan hasil penelitian diketahui tujuan dari Pembinaan Kemandirian Narapidana di Lembaga Pemasyarakatan Wirogunan Yogyakarta telah tercapai namun belum optimal karena berbagai kendala baik itu dari keterbatasan sumber daya manusia yang dimiliki lapas sekayu, begitu juga terbatasnya anggaran pembinaan di lapas Wirogunan Yogyakarta, dan akhirnya sarana dan prasarana juga tidak memadai. Tapi pembinaan kemandirian bisa tetap berjalan walaupun kurang efektif karena pemanfaatan anggaran, sumber daya manusia dan sarana dan prasarana yang dimiliki menjadi tidak optimal. Memang peningkatan pengetahuan dan keterampilan narapidana meningkat karena ada hasil yang dirasakan narapidana di mana mereka bisa memiliki keterampilan dan pengetahuan baik itu bidang pertukangan/meubelair, perkebunan/pertanian dan membatik.

\section{Penutup}

Berdasarkan hasil analisis maka kesimpulan dari Efektivitas Pembinaan Kemandirian Narapidana di Lembaga Pemasyarakatan Wirogunan Yogyakarta adalah sebagai berikut:

\section{Dilihat dari Input}

Pembinaan Kemandirian Narapidana yang selama ini dilakukan di Lembaga Pemasyarakatan Wirogunan Yogyakarta telah sesuai dengan fungsi manajemen (perencanaan, pelaksanaan, dan pengawasan). Namun dalam pelaksanaannya belum sepenuhnya dapat dilaksanakan atau dalam pengurusannya mengalami beberapa kendala. Dalam arti kata, tidak semudah dengan ketentuan yang diberlakukan. Karena terkait dengan syarat-syarat administrasi yang harus dipenuhi oleh narapidana yang akan diusulkan mendapat asimilasi kerja (pembinaan kemandirian). Di samping itu juga penyediaan sarana dan prasarana yang digunakan kurang memadai untuk 
kegiatan Pembinaan Kemandirian Narapidana.

Berdasarkan uraian di atas bisa disimpulkan jika dilihat dari input masih kurang efektif pembinaan kemandirian narapidana di Lembaga Pemasyarakatan Wirogunan Yogyakarta.

\section{Dilihat dari Proses}

Pada tahap proses pengusulan narapidana dalam pelaksanaan masih belum dilaksanakan dengan optimal karena kurangnya sosialisasi kepada narapidana sehingga yang mengikuti kegiatan asimilasi kerja sangat minim. Hal tersebut juga dipengaruhi oleh rendahnya kesadaran narapidana yang ada di Lembaga Pemasyarakatan Wirogunan Yogyakarta terhadap Pembinaan Narapidana dalam bentuk assimilasi kerja.

Pada tahap pembinaan kemandirian pertukangan/meubelair, masih banyak kekurangan dikarenakan banyak narapidana yang tidak mengikuti sosialisasi akan adanya pembinaan kemandirian pertukangan/meubelair sehingga narapidana yang mengikuti kegitan hanya sedikit. Seharusnya hal tersebut tidaklah dijadikan alasan karena dalam pembagian tugas cukup jelas dari masing-masing petugas pemasyarakatan yang terlibat dalam pembinaan narapidana.

Pada tahap pembinaan kemandirian perkebunan/pertanian, masih banyak kekurangan, karena terbatasnya pengetahuan dari petugas yang mendampingi narapidana dalam bidang perkebunan/ pertanian sehingga capaian kurang optimal.

Pada tahap pembinaan kemandirian membatik, masih banyak kekurangan karena terbatas sumber daya manusia di mana petugas yang bertanggung jawab hanya 2 orang dan juga pengetahuan tentang membatik juga sangatlah terbatas dan juga hasil dari pembinaan kemandirian masih sulit dalam pemasarannya.

Berdasarkan uraian di atas bisa disimpulkan jika kita lihat dari proses masih kurang efektif pembinaan kemandirian narapidana di Lembaga Pemasyarakatan Wirogunan Yogyakarta.

\section{Dilihat dari Output}

Tujuan umum dari Pembinaan Kemandirian Narapidana di Lembaga Pemasyarakatan Wirogunan Yogyakarta yaitu meningkatnya keterampilan dan pengetahuan narapidana belum sepenuhnya tercapai. Berdasarkan dari uraian di atas bisa disimpulkan jika lihat dari output bisa dikatakan kurang efektif pembinaan kemandirian narapidana di Lembaga Pemasyarakatan Wirogunan Yogyakarta karena masih banyaknya kendala di mana pemanfaatan sarana dan prasarana tidak optimal, 
sumber daya manusia yang terbatas dan terbatasnya anggaran untuk pembinaan dalam DIPA lapas Wirogunan Yogyakarta.

Namun demikian telah ada kemajuan keterampilan dan pengetahuan yang dimiliki narapidana dari pembinaan kemandirian yang dilaksanakan walaupun belum optimal dari tujuan yang diharapkan dari pembinaan kemandirian narapidana seperti dituangkan dalam Sistem Pemasyarakatan.

\section{Saran-Saran}

Adapun saran yang dapat direkomendasikan di dalam penelitian ini adalah sebagai berikut:

1. Untuk meningkatkan Pembinaan Kemandirian Narapidana di Lembaga Pemasyarakatan Wirogunan Yogyakarta perlu adanya dukungan dana baik itu bersumber dari DIPA di Kementerian Hukum dan HAM, juga bisa berasal dari HIBAH Pemerintah Kota Yogyakarta dan pihak swasta yang ada di Kota Yogyakarta. Dengan sumber dana yang memadai akan berperan besar dalam terlaksananya pembinaan kemandirian narapidana lebih efektif dan efisien di masa yang akan datang.

2. Dalam rangka meningkatkan kinerja pelaksanaan para penanggung jawab Pembinaan Kemandirian Narapidana dalam mencapai sasaran dan tujuan maka diperlukan peningkatan sumber daya manusia para petugas lembaga pemasyarakatan dengan mengikutsertakan dalam program pendidikan dan pelatihan keterampilan baik yang diselenggarankan oleh Kementerian Hukum dan HAM maupun oleh pihak lain. Sehingga para petugas yang terlibat dalam Pembinaan Kemandirian Narapidana menjadi lebih terampil dan menguasai pengetahuan.

\section{Daftar Pustaka}

Bryson. 1992. Analisa Penelitian. Yogyakarta: Liberty Press.

Nazir, Ali. (1999). Metode Penelitian dan Statistika. Jakarta: LP3ES.

Singarimbun, Masri dan Effendi. (1995). Metode Penelitian Survey. Jakarta: LP3ES.

Strauss, Anslem dan Yuliet Corbin. (1990). Basic of Quality Research: Grounded Theory

Procedures and Techniques. Sage Publications. The International Professional

Publisher Newbury Park London New Delhi

Sugiono. 2003. Metode Penelitian Administrasi. Bandung: Alfabeta

Undang-undang No. 12 Tahun 1995 tentang Pemasyarakatan. 